\section{Predictors of shingles reports at diagnosis of common variable immunodeficiency and selective immunoglobulin G subclass deficiency in $\mathbf{2 1 2}$ Alabama adults}

\author{
James C. Barton, 1,2,3 J. Clayborn Barton, ${ }^{2}$ \\ Luigi F. Bertoli ${ }^{1,2}$
}

'Brookwood Medical Center, ${ }^{2}$ Southern Iron Disorders Center, ${ }^{3}$ Department of Medicine, University of Alabama at Birmingham, Birmingham, AL, USA

\section{Abstract}

We sought to determine predictors of shingles reports in adults with common variable immunodeficiency or immunoglobulin (Ig) G subclass deficiency (CVID/IgGSD). We tabulated observations at diagnosis of CVID/IgGSD in 212 white adult index patients (165 women, 47 men) who responded to a question about having had shingles. None had been vaccinated for herpes zoster. We analyzed age, sex, and shingles reports; blood levels of CD19+, CD4+, CD8+, and CD56+ mononuclear cells; serum levels of IgG subclasses, IgA, and IgM; and positivity for human leukocyte antigen (HLA)-A and -B haplotypes. Cell counts and immunoglobulin levels were normalized with $\log _{\mathrm{e}}(\mathrm{ln})$ transformation for analyses. Thirty-one patients (14.6\%) reported shingles; 11 reported recurrent or disseminated shingles. Patients with shingles reports had greater mean age at diagnosis of CVID/gGSD [54 \pm 13 (standard deviation) years $v s .47 \pm 12$ years; $\mathrm{P}=0.0130$ ] and a greater prevalence of HLA-A $* 01, B^{*} 08$ positivity (35.5\% vs. 17.7\%; $\mathrm{P}=0.0227)$. In a 13 -factor logistic regression model, there was a positive association of age with shingles reports $[\mathrm{P}=0.0151$; odds ratio $(1.05,95 \%$ confidence interval $1.01,1.08)]$. HLA-A*01, B*08 positivity was also positively associated with shingles reports $[\mathrm{P}=0.0480$; odds ratio $2.61(1.00,6.81)]$. During a mean followup interval of 7.5 years after CVID/IgGSD diagnosis, the prevalence of recurrent shingles was almost five-fold greater in patients with previous shingles reports. In conclusion, in white adults at CVID/IgGSD diagnosis, age at diagnosis and positivity for HLA-A* 01 , $\mathrm{B}^{*} 08$ have significant positive associations with reports of previous shingles.

\section{Introduction}

Herpes zoster (zoster, shingles) is a localized and often painful cutaneous eruption due to reactivation of latent varicella-zoster virus (VZV) after initial infection. Approximately $98 \%$ of adults in the US have been infected by VZV and it has been estimated that one in three adults will develop herpes zoster. ${ }^{1}$ Some persons develop recurrent episodes of zoster, eye involvement, post-herpetic neuralgia, or disseminated zoster with involvement of multiple sites or organs. ${ }^{1}$ Herpes zoster occurs more frequently in older adults and in immunocompromised persons. ${ }^{1,2}$ Deaths attributable to zoster are uncommon, but typically occur in immunocompromised persons. ${ }^{1}$

Common variable immunodeficiency (CVID) and immunoglobulin (Ig) G subclass deficiency (IgGSD) are phenotypically and genetically heterogeneous disorders characterized by recurrent or severe infections of the upper and lower respiratory tract or other sites, selective deficiencies of immunoglobulin isotypes, and impaired antibody responses to common bacterial polysaccharide and protein antigens. Some patients with CVID/IgGSD also have decreased numbers or function of blood lymphocyte subsets, autoimmunity, or chronic inflammation. . $^{3-5}$ In Alabama whites, CVID/IgGSD immunophenotypes in many patients segregate with markers on chromosome $6 \mathrm{p}$ and a candidate gene(s) exists in the human leukocyte antigen (HLA) class II region..$^{6-9} \mathrm{~A}$ small proportion of patients with CVID phenotypes have mutations of genes TNFRSF13B (chromosome 17p11.2), ICOS (chromosome 2q33), TNFRSF13C (chromosome 22q13.2), or CD19 (chromosome 16p11.2); autosomal dominant CVID has been linked to chromosome 4q. ${ }^{4,5}$

Our informal experience suggested that some adults diagnosed to have CVID/IgGSD give histories of having had shingles, including recurrent or disseminated infections, but that most studies of VZV infection in patients with CVID describe pediatric cases. ${ }^{10-13}$ Thus, we performed a retrospective evaluation to characterize shingles in 212 white adults with CVID/IgGSD and to determine the relationships of age at diagnosis of CVID/IgGSD, sex, blood mononuclear cell subset levels, serum immunoglobulin isotype levels, and HLA-A and -B haplotypes with reports of shingles that occurred before diagnosis of CVID/IgSD. Our observations are discussed in the context of previous reports of factors that appear to provide defense against (or increase risk of) herpes zoster.

\section{Materials and Methods}

\section{Patient selection}

The performance of this work was approved by the Institutional Review Board of Brookwood Medical Center. All patients reported herein were referred to a hematology and
Correspondence: James C. Barton, Southern Iron Disorders Center, Suite 626, 2022 Brookwood Medical Center Drive, Birmingham, AL 35209, USA.

Tel. + 1.205.877.2888 - Fax +1.205.877.2039.

E-mail: ironmd@isp.com

Key words: herpes zoster, human leukocyte antigen, hypogammaglobulinemia, immune deficiency.

Contributions: JaCB and LFB conceived the study; JaCB and JClB tabulated the data and performed statistical analyses; JaCB, JClB, and LFB drafted the manuscript and approved its final form.

Conflict of interests: the authors report no potential conflict of interests.

Acknowledgments: this work was supported in part by Southern Iron Disorders Center.

Received for publication: 23 October 2011. Revision received: 16 April 2012.

Accepted for publication: 28 May 2012.

This work is licensed under a Creative Commons Attribution NonCommercial 3.0 License (CC BYNC 3.0).

(c) Copyright J.C. Barton et al., 2012

Licensee PAGEPress, Italy

Infectious Disease Reports 2012; 4:e34

doi:10.4081/idr.2012.e34

medical oncology practice for further evaluation and management because they had increased frequency or severity of infections uncontrolled by antibiotic therapy and evidence of hypogammaglobulinemia.

We defined probable CVID in accordance with the criteria of the Pan-American Group for Immunodeficiency and the European Society for Immunodeficiency. ${ }^{14}$ In adults, these criteria include men or women with a decrease of serum IgG and IgA at least 2 standard deviations (SD) below the mean for age; absent isohemagglutinins or poor response to vaccines; and exclusion of other defined causes of hypogammaglobulinemia. ${ }^{14}$ There is no generally accepted definition of IgGSD. In one reference, IgGSD was defined as deficiency of one or more $\operatorname{IgG}$ subclasses $\left(\operatorname{IgG}_{1-3}\right)$ at least 2 SD below the mean for age in the presence of normal total serum IgG levels, with or without IgA deficiency. ${ }^{15}$ We defined that patients with subnormal total IgG levels but whose IgA levels were normal also had IgGSD. Each patient diagnosed to have IgGSD in the present study was also demonstrated to have impaired response to polysaccharide antigens of Streptococcus pneumoniae and had no other defined cause of hypogammaglobulinemia.

We performed a computerized and manual 
search of charts of all white adults ( $\geq 18$ years of age) in our practice who were referred as outpatients in the interval 1998-2008 because they had recurrent or severe infections, typically of the upper and lower respiratory tract, and who were diagnosed to have CVID/IgGSD. ${ }^{7,14,15} \mathrm{We}$ designated the first persons in respective families diagnosed to have CVID/IgGSD as index patients. All index patients resided in central Alabama.

For final analyses, we included the 212 index patients whose charts: i) documented laboratory testing to establish their diagnosis of CVID/IgGSD, including flow cytometric analysis of blood mononuclear cells and HLA-A and -B haplotyping; ii) included responses to a question about history of shingles (or herpes zoster) diagnosed by a physician; and iii) contained a physician's recommendation that they be treated with either intravenous or subcutaneous IgG because they had serious or recurrent infections. Most index patients were diagnosed to have CVID before zoster vaccine was licensed in the US in May 2006. ${ }^{1}$ No index patient diagnosed to have CVID/IgGSD herein reported that he/she had received zoster vaccine.

\section{Patient exclusions}

We excluded subjects with isolated deficiencies of IgA or IgM, normal immunoglobulin levels with deficiency of selective antibody specificity for Streptococcus pneumoniae polysaccharide antigen(s), or hypogammaglobulinemia attributed to B-cell neoplasms, organ transplantation, immunosuppressive therapy, or increased immunoglobulin loss. We excluded patients known to have infection with human immunodeficiency virus (HIV). We excluded shingles reports of three index patients (1.4\%) because subsequent clinical and laboratory evaluations indicated that their recurrent skin eruptions were due to herpes simplex (eczema herpeticum).

We excluded persons of African American descent because: i) certain HLA types and haplotypes differ significantly among Caucasians and African Americans in central Alabama; $; 6$ ii) in adults, mean serum concentrations of immunoglobulins are often greater in persons of sub-Saharan African descent than in whites, ${ }^{19,20}$ and iii) persons of sub-Saharan descent occur infrequently in series of CVID or IgGSD patients, ${ }^{3}$ and such patients are also uncommon in our experience.

\section{Laboratory methods}

Testing was performed at diagnosis of CVID/IgGSD before IgG replacement therapy was initiated. No patient had herpes zoster at diagnosis. Serum concentrations of total IgG, IgG subclasses, IgA, and IgM were measured using standard automated methods. Reference ranges for serum immunoglobulin concentrations are: total IgG 700-1600 mg/dL; $\operatorname{IgG}_{1} 422$ -
$1292 \mathrm{mg} / \mathrm{dL} ; \operatorname{IgG}_{2}$ 117-747 mg/dL; IgG 3 41-129 $\mathrm{mg} / \mathrm{dL} ; \operatorname{IgG}_{4} 1-291 \mathrm{mg} / \mathrm{dL} ;$ total IgA $70-400$ $\mathrm{mg} / \mathrm{dL}$; and IgM 40-230 mg/dL. The lower and upper reference limits represent 2 SD below and above the corresponding mean value. ${ }^{7}$ Immunoglobulin deficiency was defined as a serum concentration was less than the corresponding lower reference limit; subnormal levels were confirmed in each patient. Reference ranges for blood levels of mononuclear cell subsets measured using flow cytometry are: CD19+ 12-645 cells/ $\mu \mathrm{L} ; \mathrm{CD} 3+622-2,402$ cells/ $\mu \mathrm{L} ; \mathrm{CD} 4+359-1,519$ cells $/ \mu \mathrm{L} ; \mathrm{CD} 8+109$ 897 cells $/ \mu \mathrm{L}$; and CD56+ 24-406 cells $/ \mu \mathrm{L}$.

HLA-A and -B alleles were detected using low-resolution DNA-based typing (polymerase chain reaction/sequence-specific oligonucleotide probe) in index cases. ${ }^{7}$ HLA typing of family members of some index cases was performed to permit assignment of chromosome $6 \mathrm{p}$ haplotypes. In each index patient in whom a single A or B allele was detected by DNA-based typing, we verified the allele(s) and set phase to ascertain haplotypes of the index patient using HLA analyses of appropriate family members. Haplotypes were defined only by $\mathrm{A}$ and $\mathrm{B}$ alleles.

\section{Statistical considerations}

Analyses were performed with Excel $2000^{\circledR}$ (Microsoft Corp., Redmond, WA) and GB-Stat ${ }^{\circledR}$ (v. 10.0, 2003, Dynamic Microsystems, Inc., Silver Spring, MD). Loge (ln) transformation normalized the blood mononuclear cell subset counts and serum immunoglobulin levels. Serum levels of $\operatorname{IgG}_{4}$ below the detection threshold of $1 \mathrm{mg} / \mathrm{dL}$ were imputed as 0.5 $\mathrm{mg} / \mathrm{dL}$ to permit ln transformation and inclusion of the data in all analyses.

We compiled four common HLA-A and -B haplotypes in the present cases that are associated with increased risk of CVID/IgGSD in central Alabama whites: $A^{*} 01, B^{*} 08 ; A^{*} 03$, B*07; $\quad A^{*} 02, \quad B * 44 ; \quad$ and $\quad A^{*} 29, \quad B * 44 .{ }^{6,7}$ Preliminary univariable and regression analyses revealed that positivity for $\mathrm{A}^{*} 01, \mathrm{~B}^{*} 08$ was the only potential HLA haplotype predictor of shingles reports. We did not include $\mathrm{CD}^{+}$ mononuclear cell counts, $\mathrm{CD} 4^{+} / \mathrm{CD} 8^{+}$ratios, or total serum IgG levels in regression analyses because these values are derivatives of or are less specific than $\mathrm{CD}^{+}{ }^{+}$and $\mathrm{CD} 8^{+}$cell counts or IgG subclass levels alone. In a final thirteenfactor logistic regression model, we used reports of having (or not having) shingles as the dependent variable. The independent variables included: i) age at diagnosis; ii); sex; iii) In-transformed blood levels of $\mathrm{CD}_{19}{ }^{+}, \mathrm{CD} 4^{+}$, $\mathrm{CD}^{+}$, and $\mathrm{CD}^{2} 6^{+}$mononuclear cells; iv) Intransformed serum levels of $\operatorname{IgG}_{1}, \operatorname{IgG}_{2}, \operatorname{IgG}_{3}$, $\operatorname{IgG}_{4}$, IgA, and IgM; and v) positivity for $A^{*} 01$, B*08.

Descriptive data are displayed as enumerations, percentages, mean $\pm 1 \mathrm{SD}$, or mean [ $95 \%$ confidence intervals (CI)]. Mean values were compared using a student t-test (two-tail). Frequency values were compared using chisquare analysis or Fisher exact test (one-tail), as appropriate. Correlations were expressed as Pearson correlation coefficient. A value of $\mathrm{P}<0.05$ was defined as significant.

\section{Results}

\section{General characteristics of 212 index patients}

The mean age of all 212 patients was $48 \pm 13$ years. Eleven patients (5.5\%) had CVID. Two hundred and one patients (94.5\%) had IgGSD; 75 of them (37.3\%) had subnormal total IgG levels but their IgA levels were within the reference limits. The mean total IgG levels in patients with CVID was lower than that of patients with IgGSD $[521 \mathrm{mg} / \mathrm{dL}(449,604) v s$. $777 \mathrm{mg} / \mathrm{dL}(748,806)$, respectively; $\mathrm{P}=0.0001$ ]. Women comprised $77.8 \%$ of this cohort of 212 patients. Eight of 11 patients with CVID (72.7\%) were women and 169 of 201 patients with IgGSD (84.1\%) were women ( $\mathrm{P}=0.2654)$.

\section{Comparisons of index patients with} and without shingles reports

Thirty-one patients (14.6\%) reported previous episodes of shingles (Table 1). The proportions of patients with CVID and IgGSD who reported shingles did not differ significantly ( $0 \%$ vs. $15.4 \%$, respectively; $\mathrm{P}=0.1678$ ). The mean age of patients with shingles reports was greater than that of patients without shingles reports. Mean levels of blood mononuclear cell subsets and serum levels of immunoglobulin isotypes in patients with or without shingles reports did not differ significantly. The proportion of patients who were positive for HLA$\mathrm{A}^{*} 03, \mathrm{~B} * 08$ was greater in those with shingles reports (Table 1 ).

\section{Shingles reports and age}

We analyzed shingles reports in patients grouped by age at CVID/IgGSD diagnosis (Figure 1). The overall prevalence in patients aged $18-49$ years was $7.1 \%$ and that of patients 50-80 years was $23.2 \%(\mathrm{P}=0.0009)$. There was a positive correlation of age and shingles reports (correlation coefficient 0.1927; $\mathrm{P}=0.0049$ ).

\section{Characteristics of shingles reports in 31 index patients}

All 31 patients with shingles reports had IgGSD. The mean age of patients at the time of initial shingles episodes was $33 \pm 16$ years (range 10-54 years) in the 11 subjects for whom this information was documented. 
Charts of 24 patients (77.4\%) documented dermatome patterns of skin eruptions, including five (13.1\%) who reported trigeminal zoster. Ten patients (32.3\%) reported recurrent shingles (2-4 episodes each). Two patients (6.5\%) reported cutaneous dissemination of their eruption. Post-herpetic neuralgia was documented in a 38 year-old woman who developed trigeminal neuralgia after having had shingles on her face.

\section{Predictors of shingles reports in a logistic regression model}

In a 13-factor logistic regression model, age was a positive predictor of shingles reports $[\mathrm{P}=0.0151$; odds ratio $(1.05(1.01,1.08)]$. HLA$\mathrm{A}^{*} 01, \mathrm{~B}^{*} 08$ positivity was also a positive predictor of shingles reports $[\mathrm{P}=0.0480$; odds ratio $2.61(1.00,6.81)]$. Odds ratios for all independent factors in the model are displayed in Figure 2. This model explained $22.3 \%$ of the variance in prediction of shingles reports.

\section{Other evaluations based on age and HLA-A*01, B*08 positivity}

The mean blood $\mathrm{CD}^{+}$mononuclear cell level of patients aged 18-49 years was higher than that of patients aged 50-80 years [438 cells/uL $(402,482)$ vs 367 cells/uL $(326,415)$, respectively; $\mathrm{P}=0.0077]$. There was a negative correlation of age with blood $\mathrm{CD} 8^{+}$cell levels (correlation coefficient $-0.2309 ; \mathrm{P}=0.0007$ ). Comparisons of mean blood levels of CD19+, $\mathrm{CD}^{+}$, and $\mathrm{CD} 56^{+}$mononuclear cells and of $\mathrm{IgG}$ subclass, IgA, and IgM levels revealed no significant differences between patients aged 1849 years and those aged $50-80$ years.

In persons with and without HLA-A*01, $\mathrm{B}^{*} 08$, we compared mean values of age at diagnosis, blood levels of $\mathrm{CD}^{2} 9^{+}, \mathrm{CD}^{+}, \mathrm{CD}^{+}$, $\mathrm{CD}^{+}$, and $\mathrm{CD}^{+} 6^{+}$mononuclear cells, and serum levels of immunoglobulin isotypes. Index patients with $\mathrm{A}^{*} 01, \mathrm{~B}^{*} 08$ had a lower mean $\operatorname{IgG}_{2}$ level than patients without this haplotype [ $189 \mathrm{mg} / \mathrm{dL}(52,682)$ vs $244 \mathrm{mg} / \mathrm{dL}(83$, 717); $\mathrm{P}=0.0203$ ]. Other comparisons revealed no significant differences.

\section{Occurrence of shingles after diagnosis of common variable} immunodeficiency/immunoglobulin $\mathrm{G}$ subclass deficiency

We reviewed charts of the present 212 patients to determine the prevalence of shingles after diagnosis of CVID/gGSD in a mean follow-up interval of $7.4 \pm 2.3$ years during which the patients received monthly IgG replacement therapy. Eleven patients had shingles after diagnosis of immunodeficiency; each had IgGSD. The prevalence of shingles diagnosis in patients who previously reported having shingles was $16.1 \%$ (5/31). The prevalence of shin-

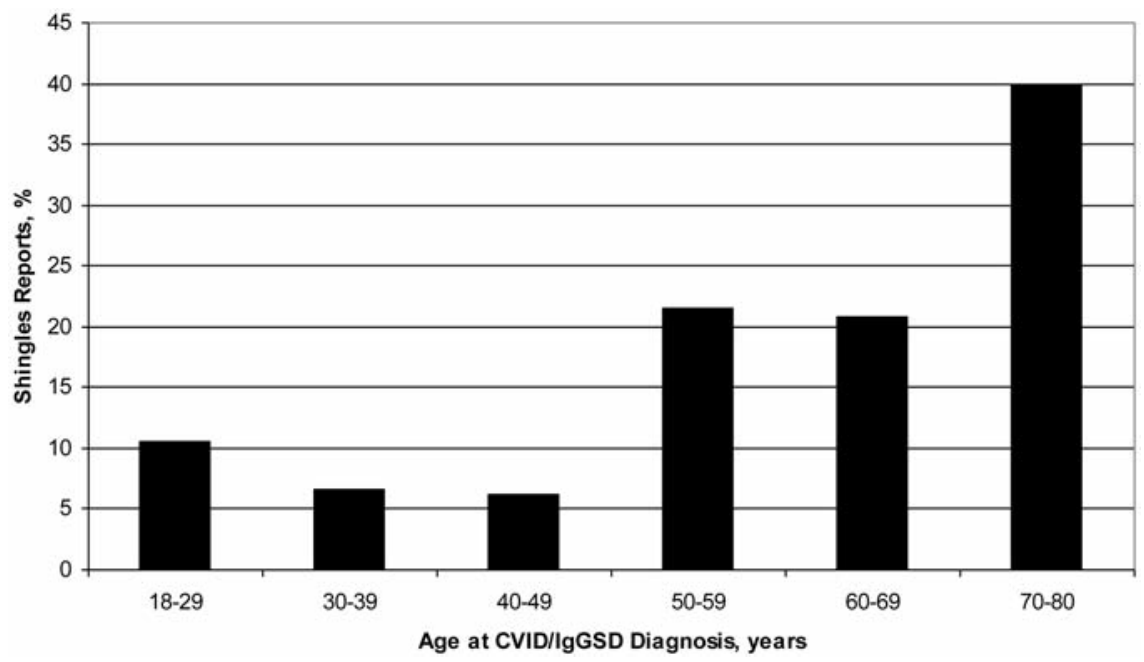

Figure 1. Reports of shingles at diagnosis of common variable immunodeficiency/IgG subclass deficiency (CVID/IgGSD) in 212 adult index patients.

Table 1. Characteristics of 212 index cases of common variable immunodeficiency/ immunoglobulin $\mathrm{G}$ subclass deficiency at diagnosis.

\begin{tabular}{|c|c|c|c|}
\hline Characteristic & $\begin{array}{l}\text { Shingles report } \\
\quad(\mathrm{n}=31)\end{array}$ & $\begin{array}{l}\text { No shingles report } \\
\qquad(\mathrm{n}=181)\end{array}$ & Value of $p$ \\
\hline Mean age, y & $54 \pm 13$ & $47 \pm 12$ & 0.0130 \\
\hline Women, \% (n) & $80.6(25)$ & $77.2(140)$ & 0.6830 \\
\hline Lymphocytes $\left(\times 10^{3} / \mu \mathrm{L}\right)$ & $1.8(0.7,4.8)$ & $1.9(0.9,4.0)$ & 0.5079 \\
\hline CD19+ cells/ $\mu \mathrm{L}$ & $231(51,1041)$ & $207(45,958)$ & 0.4550 \\
\hline CD3+ cells $/ \mu \mathrm{L}$ & $1232(388,3,916)$ & $1,398(641,3,049)$ & 0.2498 \\
\hline CD4+ cells $/ \mu \mathrm{L}$ & $786(215,2,880)$ & $922(366,2,322)$ & 0.2161 \\
\hline CD8+ cells $/ \mu \mathrm{L}$ & $375(93,1,514)$ & $409(139,1,200)$ & 0.5229 \\
\hline CD56+ cells/ $\mu \mathrm{L}$ & $148(39,572)$ & $115(26,502)$ & 0.0617 \\
\hline Total IgG, mg/dL & $752(407,1,392)$ & $761(440,1,318)$ & 0.8351 \\
\hline $\operatorname{IgG}, \mathrm{mg} / \mathrm{dL}$ & $422(198,897)$ & $415(221,779)$ & 0.8317 \\
\hline $\mathrm{IgG}_{2}, \mathrm{mg} / \mathrm{dL}$ & $206(59,721)$ & $237(78,722)$ & 0.2614 \\
\hline $\mathrm{IgG}_{3}, \mathrm{mg} / \mathrm{dL}$ & $34(3,135)$ & $34(11,102)$ & 0.9870 \\
\hline $\mathrm{IgG}_{4}, \mathrm{mg} / \mathrm{dL}$ & $14(2,88)$ & $13(1,135)$ & 0.5615 \\
\hline IgA, mg/dL & $159(42,611)$ & $147(43,503)$ & 0.5440 \\
\hline $\mathrm{IgM}, \mathrm{mg} / \mathrm{dL}$ & $82(14,474)$ & $87(20,389)$ & 0.6936 \\
\hline HLA-A*01, B*08, \% (n) & $35.5(11)$ & $17.7(32)$ & 0.0227 \\
\hline HLA-A*02, B*44, \% (n) & $19.4(6)$ & $24.3(44)$ & 0.5482 \\
\hline HLA-A*03, B*07, \% (n) & $3.2(1)$ & $7.2(13)$ & 0.3627 \\
\hline HLA-A*29, B*44, \% (n) & $6.5(2)$ & $6.6(12)$ & 0.6645 \\
\hline
\end{tabular}

Age data are presented as mean \pm 1 standard deviation. Data on cell counts and immunoglobulin isotypes are presented as mean (95\% confidence interval). Immunoglobulin isotype levels were measured using serum. Blood mononuclear cells were characterized by CD surface antigen positivity measured by flow cytometry. HLA haplotype positivity data are reported as percentages of positive subjects. Ig, immunoglobulin; HLA, human leukocyte antigen. 
gles diagnosis in patients who did not previously report having shingles was $3.3 \%$ (6/181). These proportions differed significantly $(\mathrm{P}=0.0119)$. The mean length of follow-up of the groups was similar $(7.6 \pm 2.2$ years and $7.4 \pm 2.8$ years, respectively; $\mathrm{P}=0.8556)$. Five of six patients who reported having recurrent shingles before diagnosis of CVID/IgGSD had one or more additional episodes of shingles after they began receiving IgG replacement therapy.

\section{Discussion}

In the present study of CVID/IgGSD index patients, the mean age of patients with shingles reports was greater than that of patients who reported no shingles. We observed a greater prevalence of shingles reports in patients aged $\geq 50$ years at diagnosis of CVID/IgGSD than in younger index patients, consistent with previous studies of subjects not stated to have CVID/IgGSD. ${ }^{1,221}$ Further, age was a significant independent predictor of shingles reports in the present regression analyses, although elevation of the odds ratio for shingles reports associated with age was minimal. Age is the most important risk factor for development of zoster in persons not specified to have CVID/IgGSD. ${ }^{1}$ In large studies of US cohorts, shingles risk increases significantly with age. ${ }^{1,2,22}$ In more than 4 million US health plan enrollees, shingles had occurred in $13.6 \%$ of persons aged $40-49$ years and in
$16.0 \%$ of persons aged $50-59$ years. $^{2}$ We observed that the overall prevalence of shingles reports in the present cohort was $14.6 \%$ at mean age of diagnosis of CVID/IgGSD of $48 \pm 13$ years. Taken together, these observations suggest that the age-related risk of shingles in CVID/IgGSD patients is similar to that in nonCVID/IgGSD cohorts.

In a probability sample of communitydwelling persons >64 years old in North Carolina, Schmader et al. reported that interviewers administered a comprehensive health survey to 3206 participants that included questions about lifetime occurrence of shingles. ${ }^{23}$ After controlling for age, cancer, and demographic factors, blacks were one-fourth as likely as whites (adjusted odds ratio $0.25,95 \%$ confidence interval $0.18-0.35 ; \mathrm{P}=0.0001$ ) to have experienced zoster. Thus, blacks had a significantly lower risk of developing herpes zoster than whites. ${ }^{23}$ In the present study, all patients were white. The percentage of the present white patients who reported having had zoster did not differ significantly from that in the study by Schmader et al. ${ }^{23}$ (14.3\% vs $16.1 \%$, respectively; $\mathrm{P}=0.5621)$. Zoster risk was greater in women than men in some reports. ${ }^{1,2,24}$ The prevalence of shingles reports we observed in women did not differ significantly from that in men, and sex was not a significant independent predictor of shingles reports, consistent with other studies. ${ }^{1,25}$ Recurrent herpes zoster and cutaneous dissemination were relatively common in the present index patients, consistent with charac- teristics of zoster in persons with immunocompromise due to conditions other than CVID/IgGSD. ${ }^{26-28}$

Cases of recurrent shingles were identified by Yawn et al. in 669 persons 22 years of age or older in Minnesota who had a medically documented initial episode of shingles. ${ }^{29}$ Ninetyfive of the 1669 (5.7\%) had one or more recurrences of shingles during a mean follow-up interval of 7.3 years. Participants in this Minnesota cohort identified as having immunocompromise had a 2.35 hazard ratio for recurrent shingles. ${ }^{29}$ In the present study, ten patients $(32.3 \%)$ reported recurrent shingles at diagnosis of CVID or IgGSD during a mean follow-up interval of 7.4 years. The observations in the present study and those of Yawn et al. support the conclusion that the prevalence of recurrent shingles is relatively high in persons whose immunity is decreased.

In the present study, there was a preponderance of women in both CVID and IgGSD subgroups, consistent with our previous report. ${ }^{7}$ The proportions of men and women in CVID cohorts typically do not differ significantly. ${ }^{3}$ In another report, there was a predominance of women among adults with IgG3 deficiency. ${ }^{30}$ The proportion of patients with CVID who also have or eventually develop autoimmune disorders is relatively high. ${ }^{14}$ The prevalence of autoimmune disorders is widely acknowledged to be greater in women than men. ${ }^{31,32}$ Our informal experience suggests that such patients are preferentially referred to our practice and thus could explain the predominance of women in the present cohort. Regardless, sex was not a significant predictor of risk for shingles reports in this study.

Cell-mediated immunity is important in the development of zoster and its manifestations. ${ }^{1}$ T-lymphocytes of helper/inducer phenotype $\left(\mathrm{CD}^{+}\right.$or $\left.\mathrm{Leu} \mathrm{a}^{+}\right)$proliferate in response to $\mathrm{VZV},{ }^{33-36}$ although proliferation testing is not a sensitive predictor of cellular immune compromise or risk of opportunistic infection. ${ }^{37}$ Helper/inducer T-lymphocytes are prominent in skin biopsy specimens from active herpes zoster lesions. ${ }^{34}$ Some functional properties of $\mathrm{CD} 4^{+}$cells are enhanced after exposure to VZV in vitro. ${ }^{33,38-40}$ In the present study, the levels of CD4+ blood mononuclear cells were not associated with shingles reports in univariable and regression analyses. It is unknown if numerical, proliferation, or functional deficits of CD4 ${ }^{+}$ cells existed in the present shingles patients before they developed herpes zoster. In previous studies of patients with CVID, circulating $\mathrm{CD}^{+}$cells responsive to immunization were decreased. Others had increased numbers of $\mathrm{CD}^{+}$cells, but the rate of apoptosis of these cells was also increased. ${ }^{41-43}$

The numbers and cytotoxic activity of natural killer cells $\left(\mathrm{CD} 16^{+}\right.$, Leu7 ${ }^{+}$, or $\left.\mathrm{CD}^{2} 6^{+}\right)$are depressed in the acute phase of herpes zoster,

Figure 2. Odds ratios for reports of shingles at diagnosis in 212 Alabama index patients at diagnosis of common variable immunodeficiency or immunoglobulin $\mathrm{G}$ subclass deficiency (CVID/IgGSD). $A^{*} 01, B^{*} 08$ represents positivity for human leukocyte antigen haplotype $A^{*} 01, B^{*} 08$. CD entries denote subpopulations of blood mononuclear cells. Ig entries denote serum levels of immunoglobulins. 
increase significantly in early convalescence, and return to normal in the late recovery phase. ${ }^{33,44}$ Some persons with severe deficiencies of natural killer cells have had severe VZV infections. ${ }^{45,46}$ In the present study, no patient had active or recent zoster. Mean numbers of CD56 ${ }^{+}$blood mononuclear cells did not differ significantly in patients with and without shingles reports, and blood levels of $\mathrm{CD}^{+} 6^{+}$cells were not significantly associated with shingles reports in logistic regression analyses.

Some cell-mediated immunity responses to VZV decline with age. ${ }^{35,36}$ We observed a significant negative association of age with blood levels of $\mathrm{CD}^{+}$mononuclear cells, but neither blood levels of $\mathrm{CD}^{+}$cells mononuclear nor those of $\mathrm{CD} 19^{+}, \mathrm{CD}^{+}$, or $\mathrm{CD} 56^{+}$cells were significantly associated with shingles reports in logistic regression analyses.

Primary infection with VZV is associated with early production of IgM and IgG antibodies. ${ }^{47}$ The principal anti-VZV virus isotypes in plasma from healthy donors and from convalescents after primary and reactivated disease are in $\operatorname{IgG}_{1}$ and $\operatorname{IgG}_{3}$ subclasses. ${ }^{48} \operatorname{IgG}_{4}$ antibodies were present in zoster convalescents and healthy donors but were rarely detected in varicella convalescents. Anti-VZV IgG $\mathrm{Ig}_{2}$ antibodies were found only in a few cases. ${ }^{48}$ In the present index patients with and without shingles reports, mean serum levels of respective immunoglobulin isotype levels did not differ significantly and were not significant independent predictors of shingles reports. We did observe that positivity for HLA-A*01, B*08 was greater in patients with shingles reports, and that the mean level of $\operatorname{IgG}_{2}$ was lower in index patients with HLA-A*01, $B^{*} 08$. $\operatorname{IgG}_{2}$ levels are also lower in healthy $\mathrm{A}^{*} 01, \mathrm{~B}^{*} 08$ carriers. ${ }^{49}$ Taken together, these observations suggest that the positive association of HLA-A*01, $\mathrm{B}^{*} 08$ and shingles reports we observed is not due to lower $\operatorname{IgG}_{2}$ levels. Measurement of antiVZV antibodies in CVID/IgGSD index patients was beyond the scope of the present study.

HLA-A*01, B*08 is part of a common multigene haplotype on chromosome $6 \mathrm{p}$. In Europeans, the haplotype typically includes HLA-DR3 and -DQ2. This haplotype is associated with increased risk of CVID and IgA deficiency and of systemic lupus erythematosus, myasthenia gravis, and other autoimmune disorders. ${ }^{50}$ We previously demonstrated that the prevalence of HLA-A*01, B*08 in Alabama whites with CVID/IgGSD was significantly greater than in white control subjects. ${ }^{7}$ HLA$\mathrm{A}^{*} 01, \mathrm{~B}^{*} 08$ is also associated with altered immunologic reactions to viral hepatitis and with an increased rate of progression of human immunodeficiency virus infection. ${ }^{51-55}$ The present results suggest that one or more factors in the HLA-A*01, B*08 haplotype increase the risk of shingles in patients with IgGSD. Nonetheless, the identities and roles of precise factors in the HLA-A*01, B*08 haplotype that affect manifestations of associated autoimmune and infectious diseases remain largely undefined.

Validating the accuracy of self-reports of shingles was not possible in this study. In a study of 4162 elderly persons, however, there were few false-positive and false-negative selfreports of zoster when compared to physician diagnosis. $^{56}$ All charts of the present 31 patients with shingles reports documented distinctive characteristics of herpes zoster diagnosed by a physician. Thus, it is unlikely that primary varicella infection/chicken pox was erroneously diagnosed to be herpes zoster in these cases. Taken together, these observations suggest that the shingles reports we analyzed are accurate. We cannot exclude the possibility that some patients with herpes zoster with mild manifestations did not report their condition, or that such cases were not correctly diagnosed by physicians. It is plausible but unproven that rates of shingles reports would have been higher had our case series included a greater proportion of patients with more severe immunologic abnormalities. Therefore, our prevalence estimates of shingles reports may be conservative.

\section{Conclusions}

We conclude that age is positively associated with shingles reports in white adults at CVID/IgGSD diagnosis. The age-related risk of shingles in CVID/gGSD patients is similar to that in previous studies of non-CVID/IgGSD cohorts. Recurrent herpes zoster and cutaneous dissemination were relatively common in the present index patients, consistent with characteristics of zoster in persons with immunocompromise due to conditions other than CVID/IgGSD. We observed a positive association and increased odds ratio of HLA-A* $01, B^{*} 08$ positivity with shingles reports, although the basis of this association remains unknown.

\section{References}

1. Harpaz R, Ortega-Sanchez IR, Seward JF. Prevention of herpes zoster: recommendations of the Advisory Committee on Immunization Practices (ACIP). MMWR Recomm Rep 2008;57:1-30.

2. Insinga RP, Itzler RF, Pellissier JM, et al. The incidence of herpes zoster in a United States administrative database. J Gen Intern Med 2005;20:748-53.

3. Cunningham-Rundles C, Bodian C. Common variable immunodeficiency: clinical and immunological features of 248 patients. Clin Immunol 1999;92:34-48.

4. Chapel H, Lucas M, Lee M, et al. Common variable immunodeficiency disorders: division into distinct clinical phenotypes. Blood 2008;112:277-86.

5. Park JH, Resnick ES, Cunningham-Rundles C. Perspectives on common variable immune deficiency. Ann N Y Acad Sci 2011;1246:41-9.

6. Schroeder HW Jr, Zhu ZB, March RE, et al. Susceptibility locus for IgA deficiency and common variable immunodeficiency in the HLA-DR3, -B8, -A1 haplotypes. Mol Med 1998;4:72-86.

7. Barton JC, Bertoli LF, Acton RT. HLA-A and $B$ alleles and haplotypes in 240 index patients with common variable immunodeficiency and selective IgG subclass deficiency in central Alabama. BMC Med Genet 2003;4:3.

8. Alper CA, Marcus-Bagley D, Awdeh Z, et al. Prospective analysis suggests susceptibility genes for deficiencies of IgA and several other immunoglobulins on the [HLA-B8, SC01, DR3] conserved extended haplotype. Tissue Antigens 2000;56:207-16.

9. Vorechovsky I, Cullen M, Carrington M, et al. Fine mapping of IGAD1 in IgA deficiency and common variable immunodeficiency: identification and characterization of haplotypes shared by affected members of 101 multiple-case families. J Immunol 2000;164:4408-16.

10. Asherson GL, Webster AD. Late-onset hypogammaglobulinemia. In: Diagnosis and treatment of immunodeficiency. London: Blackwell Scientific; 1980.

11. Conley ME, Park CL, Douglas SD. Childhood common variable immunodeficiency with autoimmune disease. J Pediatr 1986;108: 915-22.

12. Iglesias AJ, Matamoros FN. [Common variable immunodeficiency. Review]. Allergol Immunopathol (Madr) 2001;29:113-8. [Article in Spanish]

13. Hegazi MO, Kumar R, Alajmi M, et al. Coexistence of common variable immunodeficiency (CVID) with idiopathic thrombocytopenic purpura (ITP). Iran J Immunol 2008:5:64-7.

14. Conley ME, Notarangelo LD, Etzioni A. Diagnostic criteria for primary immunodeficiencies. Representing PAGID (PanAmerican Group for Immunodeficiency) and ESID (European Society for Immunodeficiencies). Clin Immunol 1999;93:190-7.

15. Aghamohammadi A, Louganis V, Plebani A et al. Predominantly antibody deficiencies. In: Rezaei N, Aghamohammadi A, Notarangelo D, eds. Immunodeficiency diseases: definition, diagnosis, and management. Berlin: Springer-Verlag; 2000. pp 97130.

16. Acton RT, Harman L, Go RC, et al. 
Comparison of HLA phenotypes among African Americans from Alabama, Maryland, and North Carolina. Transplant Proc 1993;25:2404-7.

17. Murphy CC, Acton RT, Barger BO, et al. Population genetic analyses of insulin dependent diabetes mellitus using HLA allele frequencies. Clin Genet 1983;23:40514.

18. Barton JC, Edwards CQ, Bertoli LF, et al. Iron overload in African Americans. Am J Med 1995;99:616-23.

19. Shulman G, Gilich GC, Andrew MJ. Serum immunoglobulins G, A and M in White and Black adults on the Witwatersrand. S Afr Med J 1975;49:1160-4.

20. Lewis M, Miyashiro M, Huton J, et al. Immunoglobulin and IgG subclass levels in the African American and Hispanic populations of east Harlem. Mt Sinai J Med 1998;65:139-45.

21. Thomas SL, Hall AJ. What does epidemiology tell us about risk factors for herpes zoster? Lancet Infect Dis 2004;4:26-33.

22. Yih WK, Brooks DR, Lett SM, et al. The incidence of varicella and herpes zoster in Massachusetts as measured by the Behavioral Risk Factor Surveillance System (BRFSS) during a period of increasing varicella vaccine coverage, 1998-2003. BMC Public Health 2005;5:68.

23. Schmader K, George LK, Burchett BM, et al. Racial differences in the occurrence of herpes zoster. J Infect Dis 1995;171:701-4.

24. Opstelten W, van Essen GA, Schellevis F, et al. Gender as an independent risk factor for herpes zoster: a population-based prospective study. Ann Epidemiol 2006;16: 692-5.

25. Donahue JG, Choo PW, Manson JE, et al. The incidence of herpes zoster. Arch Intern Med 1995;155:1605-9.

26. Tyring S, Belanger R, Bezwoda W, et al. A randomized, double-blind trial of famciclovir versus acyclovir for the treatment of localized dermatomal herpes zoster in immunocompromised patients. Cancer Invest 2001;19:13-22.

27. Whitley RJ, Soong SJ, Dolin R, et al. Early vidarabine therapy to control the complications of herpes zoster in immunosuppressed patients. N Engl J Med 1982;307: 971-5.

28. Locksley RM, Flournoy N, Sullivan KM, et al. Infection with varicella-zoster virus after marrow transplantation. J Infect Dis 1985;152:1172-81.

29. Yawn BP, Wollan PC, Kurland MJ, et al. Herpes zoster recurrences more frequent than previously reported. Mayo Clin Proc 2011;86:88-93.

30. Soderstrom T, Soderstrom R, Bengtsson U, et al. Clinical and immunological evalua- tion of patients low in single or multiple IgG subclasses. Monogr Allergy 1986;20: 135-42.

31. Quintero OL, Amador-Patarroyo MJ, Montoya-Ortiz G, et al. Autoimmune disease and gender: Plausible mechanisms for the female predominance of autoimmunity. J Autoimmun 2012;38:J109-19.

32. Selmi C, Brunetta E, Raimondo MG, et al. The $\mathrm{X}$ chromosome and the sex ratio of autoimmunity. Autoimmun Rev 2012;11: A531-7.

33. Cauda R, Prasthofer EF, Tilden AB, et al. Tcell imbalances and NK activity in varicellazoster virus infections. Viral Immunol 1987;1:145-52.

34. Baadsgaard 0, Lindskov R, Geisler C. Reduction of the number of immunocompetent cells in the acute stage of herpes zoster. Arch Dermatol Res 1987;279:374-8.

35. Burke BL, Steele RW, Beard OW, et al. Immune responses to varicella-zoster in the aged. Arch Intern Med 1982;142:291-3.

36. Levin MJ, Smith JG, Kaufhold RM, et al. Decline in varicella-zoster virus (VZV)-specific cell-mediated immunity with increasing age and boosting with a high-dose VZV vaccine. J Infect Dis 2003;188: 1336-44.

37. Stone KD, Feldman HA, Huisman C, et al. Analysis of in vitro lymphocyte proliferation as a screening tool for cellular immunodeficiency. Clin Immunol 2009; 131:41-9.

38. Hayward A, Giller R, Levin M. Phenotype, cytotoxic, and helper functions of $\mathrm{T}$ cells from varicella zoster virus stimulated cultures of human lymphocytes. Viral Immunol 1989;2:175-84.

39. Marshall JD, Wen Y, Abrams JS, et al. In vitro synthesis of IL- 4 by human CD4+ T cells requires repeated antigenic stimulation. Cell Immunol 1993;152:18-34.

40. Hayward AR, Herberger M, Lazslo M. Cellular interactions in the lysis of varicella-zoster virus infected human fibroblasts. Clin Exp Immunol 1986;63:141-6.

41. Brugnoni D, Airo P, Lebovitz M, et al. CD4+ cells from patients with common variable immunodeficiency have a reduced ability of CD40 ligand membrane expression after in vitro stimulation. Pediatr Allergy Immunol 1996;7:176-9.

42. Ravanbakhsh M, Sarafnejad A, Aghamohammadi A, et al. CD40 ligand expression on stimulated T-helper lymphocytes in patients with common variable immunodeficiency. Iran J Allergy Asthma Immunol 2007;6:129-35.

43. Giovannetti A, Pierdominici M, Mazzetta F, et al. Unravelling the complexity of T cell abnormalities in common variable immunodeficiency. J Immunol 2007;178: 3932-43.

44. Tilden AB, Cauda R, Grossi CE, et al. Demonstration of NK cell-mediated lysis of varicella-zoster virus (VZV)-infected cells: characterization of the effector cells. $\mathrm{J}$ Immunol 1986;136:4243-8.

45. Biron CA, Byron KS, Sullivan JL. Severe herpesvirus infections in an adolescent without natural killer cells. N Engl J Med 1989;320:1731-5.

46. Levy 0, Orange JS, Hibberd P, et al. Disseminated varicella infection due to the vaccine strain of varicella-zoster virus, in a patient with a novel deficiency in natural killer T cells. J Infect Dis 2003;188: 948-53.

47. Arvin AM, Koropchak CM. Immunoglobulins $\mathrm{M}$ and $\mathrm{G}$ to varicella-zoster virus measured by solid-phase radioimmunoassay: antibody responses to varicella and herpes zoster infections. J Clin Microbiol 1980;12:367-74.

48. Moyner K, Michaelsen TE. IgG subclass distribution among antibodies to varicellazoster virus in human varicella/zoster immunoglobulin preparations and the corresponding donor plasma. J Biol Stand 1988;16:157-64.

49. Candore G, Campagna AM, Cuppari I, et al. Genetic control of immune response in carriers of the 8.1 ancestral haplotype: correlation with levels of IgG subclasses: its relevance in the pathogenesis of autoimmune diseases. Ann N Y Acad Sci 2007; 1110:1518.

50. Price P, Witt C, Allcock R, et al. The genetic basis for the association of the 8.1 ancestral haplotype (A1, B8, DR3) with multiple immunopathological diseases. Immunol Rev 1999;167:257-74.

51. Descamps B, Jungers P, Naret C, et al. HLAA1, B8-phenotype association and HBs antigenemia evolution in 440 hemodialyzed patients. Digestion 1977;15: 271-7.

52. Czaja AJ, Carpenter HA, Santrach PJ, et al. Immunologic features and HLA associations in chronic viral hepatitis. Gastroenterology 1995;108:157-64.

53. Steel CM, Ludlam CA, Beatson D, et al. HLA haplotype A1 B8 DR3 as a risk factor for HIV-related disease. Lancet 1988;1: 1185-8.

54. Kaslow RA, Duquesnoy R, VanRaden M, et al. A1, Cw7, B8, DR3 HLA antigen combination associated with rapid decline of $\mathrm{T}$ helper lymphocytes in HIV-1 infection. A report from the Multicenter AIDS Cohort Study. Lancet 1990;335:927-30.

55. Cameron PU, Mallal SA, French MA, et al. Major histocompatibility complex genes influence the outcome of HIV infection. Ancestral haplotypes with $\mathrm{C} 4$ null alleles explain diverse HLA associations. Hum Immunol 1990;29:282-95.

56. Schmader K, George LK, Newton R, et al. The accuracy of self-report of herpes zoster. J Clin Epidemiol 1994;47:1271-6. 